Jurnal Akuntansi Manajemen Madani

Vol. 7, No. 1, Maret 2021

\title{
PENGARUH BAURAN PEMASARAN TERHADAP KEPUTUSAN PEMBELIAN KONSUMEN PADA MINIMARKET LINTANG MART BALIKPAPAN
}

\author{
Rahajeng Cahyaning Putri Cipto \\ STIE Madani Balikpapan \\ e-mail: ajengcipto@stiemadani.ac.id
}

\begin{abstract}
Abstrak
Penelitian ini bertujuan untuk mengetahui pengaruh harga, kualitas pelayanan, suasana toko dan lokasiterhadap keputusan pembelian konsumen pada Minimarket Lintang Balikpapan. Responden dalam penelitian ini sebanyak 163 orang, adapun metode yang digunakan dalam pengambilan sampel adalah purposive sampling. Metode analisis data dilakukan dengan regresi linear berganda menggunakan software SPSS 20. Hasil uji regresi menunjukkan bahwa variabel harga, kualitas pelayanan, suasana took dan lokasi secara simultan berpengaruh signifikan terhadap keputusan pembelian konsumen pada Minimarket Lintang Balikpapan. Hasil uji secara parsial harga, suasana toko dan lokasi berpengeruh signifikan terhadap keputusan pembelian konsumen, sedangkan kualitas pelayanan tidak berpengaruh signifikan terhadap keputusan pembelian konsumen pada Minimarket Lintang Balikpapan
\end{abstract}

Kata Kunci: Harga, Kualitas Pelayanan, Suasana Toko, Lokasi, Keputusan Pembelian

\section{PENDAHULUAN}

Salah satu usaha yang dianggap cukup ramai dalam persaingan yang semakin ketat ini adalah minimarket (Hartanto dan Haryanto, 2012:261). Minimarket merupakan toko yang menjual kebutuhan sehari-hari yang berformat modern yang dekat dengan pemukiman penduduk sehingga dapat mengungguli toko dan warung (Ma'ruf, 2005:84). Minimarket semakin banyak dibuka diberbagai tempat baik di kota besar maupun di kota kecil termasuk di kota Balikpapan.

Saat ini hampir seluruh wilayah telah banyak didirikan minimarket, bahkan dalam satu kecamatan tidak hanya terdapat satu minimarket. Banyaknya minimarket yang berdiri diduga karena perubahan selera konsumen dan juga gaya hidup masyarakat yang membuat masyarakat menuntut kenyamanan yang lebih dalam berbelanja. Semakin banyaknya minimarket yang menawarkan kelebihan dan fasilitas-fasilitas yang lebih menarik menjadikan persaingan semakin ketat, dimana setiap minimarket berusaha untuk memperluas pangsa pasar dan memperoleh konsumen sebanyak-banyaknya. Untuk menghadapi persaingan ini maka pihak minimarket harus mampu membuat serangkaian strategi pemasaran yang efektif dan selalu mengembangkan strategi 
pemasaran tersebut secara terus-menerus sebagai upaya untuk meraih keunggulan kompetitif terhadap para pesaing. Minimarket Lintang Mart merupakan salah satu tempat perbelanjaan di Balikpapan yang saat ini akan terus dan tengah berjuang untuk dapat bertahan dan bersaing dengan toko-toko pengecer dan minimarket lain yang jumlahnya semakin bertambah yang beralamat di Jalan LKMD Somber, Balikpapan Utara.

Dari data yang diperoleh peneliti terlihat bahwa penjualan di Minimarket Lintang Mart belum memenuhi target penjualan secara optimal. Selain itu Minimarket Lintang Mart mengalami penurunan penjualan di tahun 2015. Kemungkinan besar penurunan penjualan tersebut dikarenakan jumlah pengunjung yang berfluktuasi dan cenderung tidak stabil. Selain itu banyaknya minimarket-minimarket yang bermunculan membuat konsumen memiliki beragam pilihan untuk berbelanja ditempat yang menyediakan fasilitas yang lebih menarik dan nyaman untuk mereka.

Pada umumnya, sebelum melakukan pembelian biasanya konsumen akan memilih dan menentukan tempat belanja yang sesuai dengan keinginan mereka yang didasari pada faktor bauran ritel. Unsur bauran ritel tersebut adalah memberikan kualitas pelayanan yang baik. Pelayanan yang baik akan mempengaruhi calon konsumen untuk membeli dan datang lagi ke toko tersebut, karena dengan pelayanan yang memuaskan akan berdampak terjadinya pembelian yang berulang-ulang kali dan dapat meningkatkan volume penjualan. Namun saat ini cukup banyak minimarket yang memberikan kualitas pelayanan yang kurang memuaskan untuk konsumen meraka, contohnya pada beberapa konsumen Lintang Mart, berdasarkan survey awal yang peneliti lakukan terhadap beberapa konsumen tersebut menyatakan bahwa tempat parkir minimarket Lintang Mart masih kurang luas dan tidak aman, selain itu karyawan dinilai masih kurang rapi karena tidak menggunakan seragam seperti karyawan minimarket lain.

Adapun alasan memilih Minimarket Lintang Mart untuk diteliti karena Minimarket Lintang Mart lebih ramai dikunjungi konsumen walaupun tidak pernah melakukan promosi dibandingankan swalayan lain seperti Indomaret dan Alfamidi yang gencar berpromosi melalui berbagai media. Selain itu menurut peneliti Minimarket Lintang Mart sebagai tempat belanja yang ingin memperbaiki diri untuk menjadi tempat belanja yang lebih baik dibandingkan dengan pesaing yang berada disekitar. 
Pengaruh Bauran Pemasaran Terhadap Keputusan Pembelian Konsumen Pada Minimarket Lintang Mart Balikpapan; (Rahajeng Cahyaning Putri Cipto)

\section{KERANGKA TEORI}

\section{Pemasaran}

Menurut Laksana (2008:4) menyatakan bahwa pemasaran yaitu segala kegiatan yang menawarkan suatu produk untuk memenuhi kebutuhan dan keinginan konsumen. American Marketing Association (AMA) dalam Kotler dan Keller (2016:5) menyatakan bahwa pemasaran adalah suatu fungsi organisasi dan serangkaian proses untuk menciptakan, mengkomunikasikan dan memberikan nilai kepada pelanggan dan untuk mengelola hubungan pelanggan dengan cara yang menguntungkan organisasi dan pemangku kepentingannya.

\section{Harga}

Harga merupakan satu-satunya unsur bauran pemasaran yang memberikan pemasukan atau pendapatan bagi perusahaan. Tjiptono (2008:152) menyatakan bahwa harga memiliki dua peranan utama dalam proses pengambilan keputusan para pembeli, yaitu:

1. Peranan alokasi dari harga, yaitu fungsi harga dalam membantu para pembeli untuk memutuskan cara memperoleh manfaat atau utilitas tertinggi yang diharapkan berdasarkan daya belinya. Dengan demikian, adanya harga dapat membantu para pembeli untuk memutuskan cara mengalokasikan daya belinya pada berbagai jenis barang dan jasa. Pembeli membandingkan harga dari berbagai alternatif yang tersedia, kemudian memutuskan alokasi dana yang dikehendaki.

2. Peranan informasi dari harga, yaitu fungsi harga dalam 'mendidik' konsumen mengenai faktor-faktor produk seperti kualitas. Hal ini terutama bermanfaat dalam situasi di mana pembeli mengalami kesulitan untuk menilai faktor produk atau manfaatnya secara objektif. Presepsi yang sering berlaku adalah bahwa harga yang mahal mencerminkan kualitas yang tinggi.

\section{Kualitas Pelayanan}

Menurut Nursanti dan Herlina (2012:359) menyatakan bahwa kualitas pelayanan adalah kinerja yang mengarah pada mutu yang diharapkan dari yang ditawarkan secara lebih mendalam karena manfaat besar yang dihasilkan dari pelayanan, yang dapat meningkatkan intensitas pembelian dan loyalitas pelanggan. Kualitas jasa atau kualitas layanan berkontribusi signifikan bagi penciptaan diferensiasi, positioning dan strategi bersaing setiap organisasi pemasaran, baik perusahaan manufaktur maupun penyedia jasa (Tjiptono dan Chandra, 2016:113). 


\section{Suasana Toko}

Suasana atau atmosfer dalam gerai berperan penting memikat pembeli, membuat nyaman mereka dalam memilih barang belanjaan dan mengingatkan mereka produk apa yang perlu dimiliki baik untuk keperluan pribadi maupun untuk keperluan rumah tangga. Suasana yang dimaksud adalah dalam arti atmosfer dan ambience yang tercipta dari gabungan unsur-unsur desain toko/gerai, perencanaan toko, komunikasi visual dan merchandising. Suasana atau atmosfer dalam gerai meupakan salah satu unsur dalam retail marketing mix. gerai kecil yang tertata rapi dan menarik akan lebih mengundang pembeli dibandingkan gerai yang diatur biasa saja. Sementara, gerai yang diatur biasa saja tapi bersih lebih menarik daripada gerai yang tidak diatur sama sekali dan tampak kotor (Ma'ruf, 2005:201)

\section{Lokasi}

Lokasi, penentuan letak lokasi suatu restoran akan mempengaruhi kondisi keberhasilan restoran tersebut, semakin strategis lokasinya maka semakin besar pula kemungkinan sukses suatu restoran tersebut. Kestrategisan lokasi suatu restoran dapat diukur berdasarkan keadaan demografinya, jumlah pesaing dalam era lokasi tersebut, serta kondisi pasarnya. Apabila lokasi suatu restoran tersebut strategis maka akan semakin besar peluang konsumen untuk melakukan pembelian di restoran tersebut (Harry, 2014:202). Sedangkan menurut Lubis (2001) dalam Dewi (2018:16) strategi lokasi mempengaruhi kepada aspek penyaluran produk bila lokasi pemasaran dekat dengan bahan baku, maka akan mengurangi biaya yang akan dikeluarkan.

Keputusan Pembelian

Menurut Assauri (2004:25) dalam Wanda (2015:760) menyatakan bahwa keputusan pembelian merupakan suatu proses pengambilan keputusan akan pembelian yang mencakup penentuan apa yang akan dibeli atau tidak melakukan pembelian dan keputusan itu diperoleh dari kegiatan-kegiatan sebelumnya. Pengambilan keputusan merupakan suatu kegiatan individu yang secara langsung terlibat dalam mendapatkan dan mempergunakan barang yang ditawarkan.

Peter dan Olson (1999:162-163) dalam Sangadji dan Sopiah (2013:332) menyatakan bahwa inti dari pengambilan keputusan konsumen adalah proses pengintegrasian yang mengombinasikan pengetahuan untuk mengevaluasi dua perilaku alternatif atau lebih dan memilih salah satu di antaranya. Pengambilan keputusan konsumen meliputi semua proses yang 
dilalui konsumen untuk mengenali masalah, mencari solusi, mengevaluasi alternatif dan memilih diantara pilihan-pilihan.

\section{METODE PENELITIAN}

\section{Jenis Penelitian}

Penelitian yang dilakukan adalah penelitian kuantitatif deskriptif yang akan diuji lebih lanjut. Dalam penelitian ini data diperoleh dengan menggunakan kuesioner yang telah diberikan skor, yang nantinya data tersebut akan dihitung secara statistik. Data yang digunakan berupa data primer yang berasal dari data survey menggunakan kuosioner kepada pelanggan Minimarket Lintang Mart dan data sekunder berupa data penjualan yang dipeoleh dari manajemen Lintang Mart.

\section{Populasi dan Sampel}

Populasi yang dmaksud dalam penelitian ini adalah seluruh konsumen Minimarket Lintang Mart. Populasi ini merupakan populasi tak terbatas karena tidak diketahui secara pasti jumlah sebenarnya dari konsumen. Sedangkan penentuan sampel menggunakan Purposive Sampling. Purposive Sampling adalah pengambilan sampel berdasarkan pertimbangan tertentu dari peneliti sehingga sampel hanya representatif untuk populasi yang diteliti (Arifin, 2017:10). Dengan metode ini, perlu ditetapkan kriteria tertentu dalam pengambilan sampel. Sampel yang diambil dalam penelitian ini harus memiliki kriteria yaitu responden berusia minimal 17 tahun dengan asumsi pada usia tersebut responden sudah cukup dewasa sehingga dapat memahami maksud dari kuesioner yang diberikan dan pernah melakukan pembelian di Minimarket Lintang Mart Balikpapan lebih dari dua kali selama 3 bulan terakhir. Dari hasil pengambilan sampel, peneliti memperoleh jumlah sampel sebesar 212 responden tetapi terdapat 49 responden yang tidak sesuai dengan kriteria yang telah ditentukan. Dengan demikian sampel dalam penelitian ini sebesar 163 responden

\section{Metode Analisis}

Dalam penelitian ini menggunakan analisis deskripstif kuantitatif untuk mendapatkan gambaran dari responden. Selain itu analisis ini digunakan untuk penjabaran dari hasil analisis data menggunakan spss. Beberapa pengujian akan dilakukan sesuai prosedur pengujian data menggunakan spss yaitu: 


\section{Uji Asumsi klasik}

Pada Uji Asumsi Kalsik kali ini menggunakan uji normalitas yang berfungsi untuk mengetahui apakah sebaran data tersebut berdistribusi normal. Selanjutkan uji akan dilanjutkan dengan Uji Multikolinieritas yang mana bertujuan untuk melihat apakah model ini ditemukan adanya korelasi antar variable. Dilanjutkan dengan Uji Heteroskedastisitas yang bertujuan untuk melihat apakah terjadi ketidaksamaan variance dalam satu pengamatan ke pengamatan lain. Yang terakhir dilakukan uji autokorelasi yang bertujuan Uji autokorelasi bertujuan untuk menguji apakah dalam model regresi linear ada korelasi antara kesalahan pengganggu pada periode $\mathrm{t}$ dengan kesalahan pengganggu pada periode t-1 (sebelumnya). Setelah uji asumsi klasik dilakukan maka selanjutnya data di analisis dengan menggunakan Analissi Regresi Berganda.

\section{Pengujian Hipotesis}

1. Uji t: menurut Ghozali (2016:97) menyatakan bahwa Uji statistik t pada dasarnya menunjukkan seberapa jauh pengaruh satu variabel penjelas/independen secara individual dalam menerangkan variasi variabel dependen.

2. Uji F: menurut Kuncoro (2003:218) menyatakan bahwa Uji statistik F pada dasarnya menunjukkan apakah semua variabel independen atau bebas mempunyai pengaruh secara bersama-sama terhadap variabel dependen atau terikat

\section{HASIL DAN PEMBAHASAN}

Pada uji asumsi klasi dinyatakan bahwa data valid, reliable dan tidak terjadi masalh lainnya seperti heterokesdasitisa, multikolinieritad dan autokorelasi sehingga dapat dikatakan bahwa data layak digunakan dalam penelitian.

\section{Tabel 1}

\section{Hasil Uji Regresi Berganda}

\begin{tabular}{|c|c|c|c|c|c|}
\hline \multicolumn{6}{|l|}{ Coefficients $^{\mathrm{a}}$} \\
\hline \multirow[b]{2}{*}{ Model } & \multicolumn{2}{|c|}{$\begin{array}{l}\text { Unstandardized } \\
\text { Coefficients }\end{array}$} & \multirow{2}{*}{$\begin{array}{l}\text { Standardized } \\
\text { Coefficients } \\
\text { Beta }\end{array}$} & \multirow[b]{2}{*}{ I } & \multirow[b]{2}{*}{ Sig. } \\
\hline & $\mathrm{B}$ & Std. Error & & & \\
\hline $\begin{array}{ll}1 & \text { (Constant) }\end{array}$ & 13.066 & 3.067 & & 4.261 & .000 \\
\hline Harga & .164 & .115 & 126 & 1.425 & 156 \\
\hline \begin{tabular}{|l|} 
Kualitas \\
Pelayanan
\end{tabular} & -.022 & .045 & -.036 & -.477 & .634 \\
\hline
\end{tabular}




\begin{tabular}{|c|c|c|c|c|}
\hline Suasana Toko 213 & .039 & .422 & 5.459 & .000 \\
\hline Lokasi & .129 & .061 & .778 & 8 \\
\hline
\end{tabular}

a. Dependent Variable: Keputusan Pembelian Sumber : Hasil Oleh Uji SPSS 20

Berdasarkan hasil analisis diatas, maka diperoleh model persamaan regresi sebagai berikut:

$$
Y=13,066+0,164 X_{1}-0,022 X_{2}+0,213 X_{3}+0,101 X_{4}
$$

Std error $=(3,067)(0,115)(0,045)(0,039)(0,129)$

\section{Koefisien Korelasi $(\mathbf{R})$}

Koefisien korelasi berganda (R) adalah tingkat keeratan hubungan antara variabel bebas (X) dengan variabel terikat (Y). Berikut hasil pengujian koefisien koefisien dapat dilihat pada tabel dibawah ini :

\section{Tabel 2}

\section{Hasil Uji Koefisien Korelasi}

\begin{tabular}{|c|c|c|c|c|}
\hline \multicolumn{5}{|c|}{ Model Summary $^{b}$} \\
\hline Model & $\mathrm{R}$ & \begin{tabular}{|l|l} 
& Adjusted \\
R Square & R Square
\end{tabular} & $\begin{array}{l}\text { Std. Error of } \\
\text { the Estimate }\end{array}$ & Durbin-Watson \\
\hline 1 & $.495^{\mathrm{a}}$ & .245 & 3.936 & 2.024 \\
\hline $\begin{array}{l}\text { a. Prec } \\
\text { Toko, }\end{array}$ & $\begin{array}{l}\text { dictors } \\
\text { Harga }\end{array}$ & (Constant), Lokasi, & Kualitas Pela & yanan, \\
\hline
\end{tabular}

Sumber : Hasil Oleh Uji SPSS 20

Berdasarkan hasil uji diatas diperoleh nilai R sebesar 0,495 ini menunjukkan bahwa hubungan kolerasi sedang antara variabel harga (X1), kualitas pelayanan (X2), suasana toko (X3) dan lokasi (X4) terhadap keputusan pembelian (Y).

\section{Koefisien Determinasi $\left(\mathbf{R}^{2}\right)$}

Koefisien determinasi $\left(\mathrm{R}^{2}\right)$ digunakan untuk mengukur seberapa jauh kemampuan model dalam menerangkan variasi variabel dependen. Hasil pengujian koefisien determinasi dapat dilihat pada tabel dibawah ini : 


\section{Tabel 3}

\section{Hasil Uji Koefisien Determinasi}

\begin{tabular}{|l|l|l|l|l|l|}
\hline \multicolumn{5}{|c|}{ Model Summary $^{\mathbf{b}}$} \\
\hline Model & R & R Square & $\begin{array}{l}\text { Adjusted } \\
\text { R Square }\end{array}$ & $\begin{array}{l}\text { Std. Error of } \\
\text { the Estimate }\end{array}$ & Durbin-Watson \\
\hline 1 & $.495^{\mathrm{a}}$ & .245 & .226 & 3.936 & 2.024 \\
\hline
\end{tabular}

a. Predictors: (Constant), Lokasi, Kualitas Pelayanan, Suasana Toko, Harga

b. Dependent Variable: Keputusan Pembelian

\section{Sumber : Hasil Oleh Uji SPSS 20}

Berdasarkan tabel diatas koefisien determinasi memiliki nilai adjusted $R$ square sebesar 0,226. Hal ini berarti 22,6\% keputusan pembelian (Y) ditentukan oleh variabel harga (X1), kualitas pelayanan (X2), suasana toko (X3) dan lokasi (X4). Sedangkan sisanya sebesar 77,4\% disebabkan oleh faktor-faktor lain yang tidak diketahui.

\section{Pengujian Hipotesis}

\section{Uji Simultan (Uji F)}

Uji $\mathrm{F}$ digunakan untuk mengetahui ada tidaknya pengaruh variabel independen terhadap variabel dependen secara simultan (bersama-sama). Hasil uji F dapat dilihat pada tabel dibawah ini :

\section{Tabel 4}

\section{Hasil Output Uji Simultan (Uji F)}

\begin{tabular}{|l|l|l|l|l|l|l|}
\hline \multicolumn{7}{|c|}{ ANOVA $^{\mathbf{a}}$} \\
\hline \multicolumn{1}{|c|}{ Model } & Sum of Squares & df & Mean Square & F & Sig. \\
\hline 1 & Regression & 795.907 & 4 & 198.977 & 12.842 & $.000^{\mathrm{b}}$ \\
\cline { 2 - 8 } & Residual & 2448.106 & 158 & 15.494 & & \\
\cline { 2 - 8 } & Total & 3244.012 & 162 & & & \\
\hline
\end{tabular}

a. Dependent Variable: Keputusan Pembelian

b. Predictors: (Constant), Lokasi, Kualitas Pelayanan, Suasana

Toko, Harga

Sumber : Hasil Oleh Uji SPSS 20

Dengan menggunakan tingkat signifikansi 5\% (0,05), maka terlebih dahulu dicari nilai $F_{\text {tabel, }} \mathrm{df}=$ jumlah variabel $-1=5-1=4$, df $2=$ jumlah data - jumlah variabel independen $-1=163-4-1=158$. Sehingga nilai $F_{\text {tabel }}$ sebesar 2,429. Dari 
perhitungan diatas dapat diketahui $\mathrm{F}_{\text {hitung }}(12,842)>\mathrm{F}_{\text {tabel }}(2,429)$, maka $\mathrm{H}_{0}$ ditolak dan $\mathrm{H}_{\mathrm{a}}$ diterima yang berarti bahwa variabel harga, kualitas pelayanan, suasana toko dan lokasi secara simultan berpengaruh signifikan terhadap keputusan pembelian konsumen pada Minimarket Lintang Mart Balikpapan.

\section{Uji Parsial (Uji t)}

Uji parsial (uji t) digunakan untuk menguji seberapa jauh pengaruh satu variabel penjelas/independen secara individual dalam menerangkan variasi variabel dependen. Hasil uji t dapat dilihat pada tabel dibawah ini :

\section{Tabel 5}

\section{Hasil Output Uji Parsial (Uji t)}

\begin{tabular}{|c|c|c|c|c|c|}
\hline \multicolumn{6}{|c|}{ Coefficients $^{\mathrm{a}}$} \\
\hline \multirow[b]{2}{*}{ Model } & \multicolumn{2}{|c|}{$\begin{array}{l}\text { Unstandardized } \\
\text { Coefficients }\end{array}$} & \multirow{2}{*}{$\begin{array}{l}\begin{array}{l}\text { Standardized } \\
\text { Coefficients }\end{array} \\
\text { Beta } \\
\end{array}$} & \multirow[b]{2}{*}{$\mathrm{T}$} & \multirow[b]{2}{*}{ Sig. } \\
\hline & B & Std. Error & & & \\
\hline $1 \quad$ (Constant) & 13.066 & 3.067 & & 4.261 & .000 \\
\hline Harga & .164 & .115 & .126 & 1.425 & .156 \\
\hline \begin{tabular}{|l} 
Kualitas \\
Pelayanan
\end{tabular} & -.022 & .045 & -.036 & -.477 & .634 \\
\hline Suasana Toko & 213 & .039 & .422 & 5.459 & .000 \\
\hline Lokasi & .101 & .129 & .061 & .778 & .438 \\
\hline
\end{tabular}

a. Dependent Variable: Keputusan Pembelian

Sumber: Hasil Oleh Uji SPSS 20

Dari hasil Uji t menunjukkan bahwa variable Harga, Kualitas Pelayanan, Suasana Toko dan Lokasi berpengaruh signifikan terhadap Keputusan Pembelian Konsumen

\section{Hasil Penelitian}

Penelitian ini bertujuan untuk mengetahui pengaruh variabel harga, kualitas pelayanan, suasana toko dan lokasi baik secara parsial maupun simultan terhadap keputusan pembelian konsumen pada Minimarket Lintang Mart yang beralamat di Jl. LKMD, Somber, Balikpapan Utara. Adapun pembahasan masing-masing variabel akan dijelaskan sebagai berikut :

a. Harga, Kualitas Pelayanan, Suasana Toko dan Lokasi secara simultan berpengaruh signifikan terhadap Keputusan Pembelian Konsumen. 
Dari hasil pengujian dalam penelitian ini diperoleh $F_{\text {hitung }} 12,842$ lebih besar dari nilai $F_{\text {tabel }}$ 2,429 dengan nilai signifikansi $F$ sebesar 0,000 yang berarti nilai signifikansi lebih kecil dari 0,05 $(0,000<0,05)$. Dari hasil uji $\mathrm{F}$ tersebut dapat disimpulkan bahwa $\mathrm{H}_{0}$ ditolak dan $\mathrm{H}_{\mathrm{a}}$ diterima yang berarti bahwa hipotesis keempat yang menyatakan variabel "harga, kualitas pelayanan, suasana toko dan lokasi secara simultan berpengaruh signifikan terhadap keputusan pembelian konsumen pada Minimarket Lintang Mart Balikpapan” diterima..

b. Harga berpengaruh signifikan terhadap Keputusan Pembelian Konsumen.

Dari hasil pengujian dalam penelitian ini diperoleh $t_{\text {hitung }}$ sebesar 1,425 lebih kecil dari nilai tabel 1,975 dengan nilai signifikansi t sebesar 0,156 yang berarti nilai signifikansi lebih besar dari 0,05 $(0,156)>0,05)$. Maka dapat disimpulkan bahwa $\mathrm{H}_{0}$ diterima dan $\mathrm{H}_{\mathrm{a}}$ ditolak yang berarti bahwa hipotesis pertama yang menyatakan variabel "harga berpengaruh signifikan terhadap keputusan pembelian konsumen pada Minimarket Lintang Mart Balikpapan” tidak dapat diterima. Hal ini menunjukkan bahwa Minimarket Lintang Mart harus lebih mempertimbangkan lagi tingkat harga yang ditetapkan walaupun dari hasil analisa jawaban responden sebagian konsumen setuju bahwa tingkat harga yang ditawarkan Minimarket Lintang Mart sudah cukup terjangkau dan mampu bersaing dengan pesaingnya yang berada disekitar dalam mempengaruhi konsumen untuk melakukan pembelian.

Harga akan menjadi pertimbangan yang cukup penting bagi konsumen dalam memutuskan pembelian. Apalagi jika produk atau jasa yang akan dibeli merupakan kebutuhan sehari-hari, misalnya makanan, minuman dan kebutuhan pokok lainnya, konsumen akan sangat memperhatikan harganya.

c. Kualitas Pelayanan tidak berpengaruh signifikan terhadap Keputusan Pembelian Konsumen.

Dari hasil pengujian dalam penelitian ini diperoleh $t_{\text {hitung }}$ sebesar -0,477 lebih kecil dari nilai $t_{\text {tabel }} 1,975$ dengan nilai signifikansi t sebesar 0,634 yang berarti nilai signifikansi lebih besar dari 0,05 (0,634 > 0,05). Maka dapat disimpulkan bahwa $\mathrm{H}_{0}$ diterima dan $\mathrm{H}_{\mathrm{a}}$ ditolak yang berarti bahwa hipotesis kedua yang menyatakan variabel "kualitas pelayanan berpengaruh signifikan terhadap keputusan pembelian konsumen 
pada Minimarket Lintang Mart Balikpapan" tidak dapat diterima. Menurut Parasuraman et.al. (1988) dalam Purnama (2006:19) menyatakan bahwa kualitas layanan merupakan perbandingan antara layanan yang dirasakan konsumen dengan kualitas layanan yang diharapkan konsumen. Jika kualitas layanan yang dirasakan sama atau melebihi kualitas layanan yang diharapkan maka layanan dikatakan berkualitas dan memuaskan.

Dari hasil penelitian menunjukkan bahwa kualitas pelayanan tidak memiliki pengaruh signifikan terhadap keputusan pembelian pada Minimarket Lintang Mart Balikpapan karena dari hasil analisa jawaban responden, konsumen tidak puas dengan pelayanan yang diberikan oleh karyawan terutama oleh bagian kasir. Kurangnya kasir pada Minimarket Lintang Mart Balikpapan mengakibatkan keterlambatan dalam transaksi pembayaran dan juga konsumen harus menunggu lama karena antrian yang panjang, selain itu beberapa konsumen tersebut menyatakan bahwa tempat parkir minimarket Lintang Mart masih kurang luas dan tidak aman sehingga hal ini perlu menjadi perhatian khusus bagi pihak Lintang Mart Balikpapan..

d. Suasana Toko berpengaruh signifikan terhadap Keputusan Pembelian Konsumen.

Dari hasil pengujian dalam penelitian ini diperoleh thitung sebesar 5,459 lebih besar dari nilai $t_{\text {tabel }} 1,975$ dengan nilai signifikansi t sebesar 0,00 yang berarti nilai signifikansi lebih kecil dari $0,05(0,00<0,05)$. Maka dapat disimpulkan bahwa $\mathrm{H}_{0}$ ditolak dan $\mathrm{H}_{\mathrm{a}}$ diterima yang berarti bahwa hipotesis ketiga yang menyatakan variabel "suasana toko berpengaruh signifikan terhadap keputusan pembelian konsumen pada Minimarket Lintang Mart Balikpapan" dapat diterima. Hasil pengujian yang menyatakan bahwa secara parsial suasana toko memiliki pengaruh signifikan terhadap keputusan pembelian menunjukkan bahwa pengelolaan suasana toko pada Minimarket Lintang Mart sudah cukup baik, hal ini terlihat dari tampilan toko yang menarik, barangbarang yang tersusun di rak yang dikelompokkan berdasarkan fungsi dan manfaatnya, pintu masuk yang lebar sehingga memudahkan akses keluar masuk ke dalam Lintang Mart serta pencahayaan ruangan yang cukup terang sehingga mampu meningkatkan daya tarik toko yang akan mempengaruhi konsumen untuk memutuskan melakukan pembelian di minimarket tersebut.

e. Lokasi berpengaruh signifikan terhadap Keputusan Pembelian Konsumen. 
Dari hasil pengujian dalam penelitian ini diperoleh $t_{\text {hitung }}$ sebesar 0,778 lebih kecil dari nilai $\mathrm{t}_{\text {tabel }} 1,975$ dengan nilai signifikansi $\mathrm{t}$ sebesar 0,438 yang berarti nilai signifikansi lebih besar dari 0,05 (0,438 > 0,05). Maka dapat disimpulkan bahwa $\mathrm{H}_{0}$ diterima dan $\mathrm{H}_{\mathrm{a}}$ ditolak yang berarti bahwa hipotesis keempat yang menyatakan variabel "lokasi berpengaruh signifikan terhadap keputusan pembelian konsumen pada Minimarket Lintang Mart Balikpapan” tidak dapat diterima. Menurut Ma'ruf (2006:115) menyatakan bahwa lokasi adalah letak dimana pengecer membuka gerainya, lokasi merupakan faktor yang sangat penting dalam bauran pemasaran ritel. Lokasi perusahaan yang tepat akan memberikan keunggulan yang dalam bersaing dan memberikan kemudahan bagi perushaan itu sendiri, sehingga akan memberikan dampak positif bagi perkembangan perusahaan.

Dari hasil penelitian menunjukkan bahwa lokasi tidak memiliki pengaruh signifikan terhadap keputusan pembelian pada Minimarket Lintang Mart Balikpapan hal ini menunjukkan bahwa Minimarket Lintang Mart memiliki lokasi yang masih kurang strategis menurut sebagian konsumen selain itu lokasi Lintang Mart ini tidak mudah dijangkau oleh transportasi umum dan juga akses menuju lokasi sangat jauh dari pusat kota. Sehingga lokasi Minimarket Lintang Mart harus menjadi fokus yang perlu dipertimbangkan oleh pihak minimarket.

\section{PENUTUP}

\section{Kesimpulan}

Penelitian ini bertujuan untuk mengetahui pengaruh variabel harga, kualitas pelayanan dan suasana toko baik secara parsial maupun simultan terhadap keputusan pembelian konsumen pada Minimarket Lintang Mart. Berdasarkan hasil penelitian dan pembahasan, maka dapat ditarik kesimpulan sebagai berikut:

1. Harga, kualitas pelayanan dan suasana toko secara simultan berpengaruh signifikan terhadap keputusan pembelian konsumen pada Minimarket Lintang Mart Balikpapan.

2. Harga berpengaruh signifikan terhadap keputusan pembelian konsumen pada Minimarket Lintang Mart Balikpapan. 
3. Kualitas pelayanan tidak berpengaruh signifikan terhadap keputusan pembelian konsumen pada Minimarket Lintang Mart Balikpapan.

4. Suasana toko berpengaruh signifikan terhadap keputusan pembelian konsumen pada Minimarket Lintang Mart Balikpapan.

5. Lokasi berpengaruh signifikan terhadap keputusan pembelian konsumen pada Minimarket Lintang Mart Balikpapan

\section{Saran}

Dengan diketahuinya variabel harga yang berpengaruh signifikan terhadap keputusan pembelian, maka pihak Minimarket Lintang Mart disarankan untuk tetap mempertahankan harga yang ditawarkan, agar konsumen tidak berpindah toko dan terus melakukan pembelian di Minimarket Lintang Mart. Pihak Lintang Mart juga dapat mencoba meningkatkan keputusan pembelian konsumen dengan memberikan diskon atau voucher belanja kepada pelanggan. Dari variabel suasana toko juga berpengaruh signifikan terhadap keputusan pembelian, sehingga disarankan agar dapat mempertahankan pengelolaan suasana toko yang sudah baik dan dapat memperhatikan kembali pengelolaan suhu udara dalam ruangan. Pihak Lintang Mart dapat mencoba untuk mengatur pengelolan sirkulasi udara pada ruangan agar suhu ruangan menjadi sejuk yaitu dengan mengatur penempatan kipas angin pada area yang dapat mencakup semua ruangan. Dari variabel kualitas pelayanan tidak berpengaruh signifikan terhadap keputusan pembelian, sehingga disarankan agar kualitas pelayanan yang diberikan pihak Lintang Mart hendaknya lebih ditingkatkan lagi yaitu dengan menambah tenaga kerja pada bagian kasir agar tidak terjadi antrian panjang serta lebih meningkatkan keramahan dan kesopanan pegawai dalam menangani keluhan konsumen.

\section{DAFTAR PUSTAKA}

Arifin, Johar. 2017. SPSS 24 Untuk Penelitian dan Skripsi. PT Elex Media Komputindo. Jakarta.

Ariyanti, Hari. 2017. Aprindo: Penyebab Tutupnya Toko Ritel Bukan Karena Online.https://m.merdeka.com/uang/aprindo-bukan-karena-online-penyebab-tutupnyatoko-ritel.html. 5 Januari 2018. (1:32).

Djakaria, Ruth Yanti. 2017. Pengaruh Kualitas Pelayanan, Harga, Promosi, Dan Suasana Toko Terhadap Pengambilan Keputusan Pembelian Asia Fashion. Skripsi. Universitas Sanata Dharma. Yogyakarta. 
Ferdian, M. Ruly. 2010. Analisis Faktor-Faktor Yang Mempengaruhi Loyalitas Konsumen Pada Swalayan Berkah Di Bangsri Jepara. Jurnal Sains Pemasaran Indonesia 9(3): 318-334.

Ghozali, Imam. 2016. Aplikasi Analisis Multivariate Dengan Program IBM SPSS 21. Edisi Kedelapan. Badan Penerbit Universitas Diponegoro. Semarang.

Hartanto, Adrian, dan Jony Oktavian Haryanto. 2012. Pengaruh Display, Kepercayaan Merek, Keakraban Merek, Persepsi Harga Terhadap Intensi Pembelian dan Pembelian Tak Terencana. 261-282.

Hasan, Ali. 2008. Marketing. Edisi Pertama. Media Pressindo. Yogyakarta.

Kotler, Philip, dan Gary Armstrong. 2008. Principles Of Marketing. Twelfth Edition. Pearson Education, Inc. Terjemahan Bob Sabran, MM. 2006. Prinsip-Prinsip Pemasaran. Edisi Keduabelas. Jilid 1. Erlangga. Jakarta.

Kevin Lan Keller. 2012. Marketing Manajemen. Twelfth Edition. Pearson Education, Inc. Terjemahan Bob Sabran, MM. Manajemen Pemasaran. Edisi Keduabelas. Erlangga. Jakarta.

Kevin Lan Keller. 2016. Marketing Manajemen. Thirteenth Edition. Pearson Education, Inc. Terjemahan Bob Sabran, MM. 2016. Manajemen Pemasaran. Edisi Ketigabelas. Jilid 1. Erlangga. Jakarta.

Kuncoro, Mudrajad. 2003. Metode Riset Untuk Bisnis Dan Ekonomi. Erlangga. Jakarta.

Laksana, Fajar. 2008. Manajemen Pemasaran: Pendekatan Praktis. Edisi Pertama. Graha Ilmu. Yogyakarta.

Ma'ruf, Hendri. 2005. Pemasaran Ritel. PT Gramedia Pustaka Utama. Jakarta.

Martono, Nanang. 2014. Metode Penelitian Kuantitatif: Analisis Isi dan Analisis Data Sekunder. Edisi Revisi Kedua. Cetakan Keempat. PT RajaGrafindo Persada. Jakarta.

Nurbiyati, Titik, dan Mahmud Machfoedz. 2005. Manajemen Pemasaran Kontemporer. Kayon. Yogyakarta.

Prasetyo, Bambang, dan Lina Miftahul Jannah. 2012. Metode Penelitian Kuantitatif : Teori dan Aplikasi. Edisi Pertama. Cetakan Ketujuh. PT RajaGrafindo Persada. Jakarta.

Prastuti, Hapsari. 2017. Pengaruh Retail Mix Terhadap Kepuasan Konsumen (Studi Kasus Konsumen Toserba Laris Kartasura). Skripsi. Institut Agama Islam Negeri Surakarta. Surakarta.

Priyatno, Duwi. 2012. Belajar Cepat Olah Data Statistik Dengan SPSS. Edisi Pertama. CV Andi Offset. Yogyakarta. Yogyakarta.

Purnama, Nursya'bani. 2006. Manajemen Kualitas: Perspektif Global. Edisi Pertama. Cetakan Pertama. Ekonisia. Yogyakarta. 
Pengaruh Bauran Pemasaran Terhadap Keputusan Pembelian Konsumen Pada Minimarket Lintang Mart

Sangadji, Etta Mamang, dan Sopiah. 2013. Perilaku Konsumen Pendeketan Praktis Disertai Himpunan Jurnal Penelitian. Edisi Pertama. CV Andi Offset. Yogyakarta.

Sekaran, Uma. 2006. Metodologi Penelitian Untuk Bisnis. Edisi Keempat. Salemba Empat. Jakarta.

Setiyaningrum, Ari, Jusuf Udaya, dan Efendi. 2015. Prinsip-prinsip Pemasaran: Pengenalan Plus Tren Terkini tentang Pemasaran Global, Pemasaran Jasa, Green Marketing, Entrepreneural Marketing dan E-Marketing. Edisi Pertama. Andi. Yogyakarta.

Sopiah, dan Syihabudhin. 2008. Manajemen Bisnis Ritel. Edisi Pertama. CV Andi Offset. Yogyakarta.

Sugiyono. 2013. Metode Penelitian Bisnis. Alfabeta. Bandung.

. 2015. Metode Penelitian Kuantitatif, Kualitatif, Dan Kombinasi (Mixed Methods). Cetakan Ketujuh. Alfabeta. Bandung.

. 2016. Metode Penelitian Kuantitatif, Kualitatif, Dan R\&D. Cetakan Keduapuluh Tiga. Alfabeta. Bandung.

. Statistika Untuk Penelitian. Cetakan Keduapuluh Tujuh. Alfabeta. Bandung.

Sunyoto, Danang. 2014. Dasar-Dasar Manajemen Pemasaran (Konsep, Strategi, dan Kasus). Cetakan Ketiga. CAPS (Center of Academic Publishing Service). Yogyakarta.

Suwartono. 2014. Dasar-Dasar Metodologi Penelitian. Edisi Pertama. CV Andi Offset. Yogyakarta.

Tjiptono, Fandy. 2008. Strategi Pemasaran. Edisi Ketiga. CV Andi Offset. Yogyakarta. 2015. Strategi Pemasaran. Edisi Keempat. CV Andi Offset. Yogyakarta.

Tjiptono, Fandy, dan Gregorius Chandra. 2016. Service, Quality dan Satisfaction. Edisi Keempat. CV Andi Offset. Yogyakarta.

Umar, Husein. 2000. Riset Pemasaran dan Perilaku Konsumen. Cetakan Kelima. PT Gramedia Pustaka Utama. Jakarta

. 2008. Metode Penelitian Untuk Skripsi dan Tesis Bisnis. Edisi Kedua. PT RajaGrafindo Persada. Jakarta.

Utami, Christina Whidya. 2010. Manajemen Ritel: Strategi dan Implementasi Operasional Bisnis Ritel Modern di Indonesia. Edisi Kedua. Salemba Empat. Jakarta.

Yusuf, Muri. 2014. Metode Penelitian: Kuantitatif, Kualitatif, dan Penelitian Gabungan. Edisi Pertama. Cetakan Pertama. Prenadamedia Group. Jakarta. 